\title{
WORD-FORMATING AND SEMANTIC CHARACTERISTICS ENGLISH METHODOLOGICAL VOCABULARY
}

\author{
Yulia Tsymbal \\ Postgraduate Student, National Pedagogical Dragomanov University, Ukraine \\ e-mail: hozratkulovayulia@gmail.com,orcid.org/0000-0002-7101-2880
}

\section{Summary}

In this article the morphological term creation is analyzed: affixation, conversion, general vocabulary processes and lexical-semantic relations in the English term system of education are also analyzed. The English-speaking terminology system of education is characterized as complex, stable and dynamic. Its elements are units of autochthonous language and borrowing from other languages, and the structure is isomorphic to the structure of logical connections between the concepts of the field of education. This term system is an open set, which draws from the whole variety of language tools new opportunities for expressing the values arising in the process of further development of educational activity.

Semantic terminology has always been one of the main ways to replenish terminology. As a result of the semantic method of terminology, the terminological meaning is exhausted on the rights of the lexical-semantic variant, which develops on the basis of the adjacency of the signs of what is already indicated in the previous meaning of the word and the new one, which is denoted.

Keywords: methodological vocabulary, terminology, linguistic, semantic characteristics, word-formating.

DOI: https://doi.org/10.23856/4811

\section{Introduction}

Vocabulary is one of the most important linguistic mechanisms that ensure the endless replenishment of the vocabulary of the language. Word-building ensures the functioning of the language in time, satisfies the needs of native speakers in denoting new realities.

The meaning of word creation is not exhausted only by replenishing the vocabulary of the language. Vocabulary is a form of vocabulary.

According to O.S. Kubriakova, the main task of the study of vocabulary is "the study of regularities and features of vocabulary modeling... in all its aspects - formal and meaningful, on the one hand, genetic, procedural, as well as productive, stationary, structural and functional, on the other" (Kubriakova, 1972: 350).

The processes of terminology develop according to the same laws as word formation in general. New terms are created in the same ways from the commonly used language and from the well-known vocabulary.

Word-making processes in the English-language methodological system occur in different directions. First, it is semantic derivation - internal semantic word development; secondly, word-forming derivation is the external development of words, that is, the development of a morphological and word-forming structure; thirdly, the paradigmatic development of words, or the development of semantic relations between words. 
2. Affixal method of term creation in English-language methodical vocabulary

The peculiarities of modern English are the great potential of vocabulary, including morphological wording: affixation, conversion, phrase. In this paragraph, we try to identify and systematize the most productive word-making affixes, with the help of which derived words are formed in the English-language terminology of the sphere of education. The derivative word, in the opinion of M.M. Poluzhin, usually being more complex in structure than the word simple, is more transparent and informative in meaning. They are easily formed on the basis of existing words in the language and are also easily decoded and remembered. To understand the derivative word, it is enough to know its original motivating word (Poluzhin, 1999:133).

Affixation is a way of generating words using prefixes, infixes, and suffixes that attach to the basis that serves as the basis for them.

Prefixes are derivative morphemes prepositional attached to the base. Terms formed using prefixes are joined to a certain semantic series of words. When prefixed, the categorical meaning of a given word is most often preserved and it does not pass to the other part of the language (Tsarev, 1984:15).

This type of prefix derivatives is called modification as opposed to transposition, in which the word is recategorized and is not typical of English. Prefixal wording in English has repeatedly been the subject of scientific research. A deep review of the existing literature on this issue was given by Poluzhin (Poluzhin, 1999: 28-40).

Formed with the help of prefixes teaching English terms WMS - on Classification forge on various parameters: origin - especially English prefixes mis-, un- or borrowed co-, de-, dis-, hyper-, ir- non-, post-, pre-, sub-, super; semantically - negative prefixes ir-, non-, un-; plural prefixes multi, mega, poly-; redundancy hyper-, over-; temporal and spatial locativity pre-, post-, under-.

In the studied material we distinguish prefixes that form a semantic group with a common meaning of multiplicity and redundancy hyper-, mega-, multi-, over-, poly-.Divide the prefixes into two groups of values:

1) "Many" - mega-, multi-; with their help terms are formed, which denote large educational institutions:

- megaversity - a great university with a large number of studening its divisions (separate institutions) may be in different countries;

- multiversity - type of university consisting of many faculties, each of which constitutes an independent educational institution, and the addition or exclusion of any subdivision has little effect on the fate of the university as a whole (for example, the University of California).

- The prefix multi - joining the noun and adjective bases indicates plurality, comprehensiveness:

- multiculturalism - multiculturalism, diversity of cultures;

- multilingual - multilingual;

- multimedia - a system that combines different media - udio, video, printed, computer;

2)"more than" (deviation from the norm, standard)

- hyperactivity - overactivity;

- hypertext - the principle of organization of information retrieval masses led, in which certain information elements (including including full-text, factual, graphic and others) are interconnected by associative relationswe provide a quick search for the necessary informations. The term was proposed in 1967 by T. Nell - sonom (Voroiskyi, 1998:43); 
- hypermedia (H-media ) - extension of the concept of "hypertext" to multimedia types of data records (text, audio, graphics, etc.) (Voroiskyi, 1998:181);

- polyversity - a university with a large number of faculties and by - divisions.

The prefix over- forms nouns, adjectives and verbs meaning "over - measures - ness, abuse of action that marked the foundation":

- overactivity - increased activity (activity), hyperfunction;

- overage - outgrowth;

- overlearning - excessive learning.

To convey the value of the wrong action, the prefix mis - is used: bad, wrong; marriage). He can join as names - us - co - ref bases and to the verb:

- misbehavior - bad behavior;

- miseducation - incorrect education (N. Chomsky's term);

- misteach - to teach incorrectly;

- misunderstand - misunderstand.

The next group of prefixes with the meaning of negation - dis-, ir-, non-, un("no" ). Derivatives with the prefix dis- have the meaning "opposite to that expressed by the base":

- disability - incapacity, incapacity, impotence (Nikoshkova, 2001: 88)

- disrespect - disrespect;

This prefix is also involved in the suffix-word prefixes - utvo - ren - no:

- disrespectful - not worthy of respect;

- disobedient - disobedient;

Prefix non- conveys meaning no qual - those defined basis:

- non-ability - inability;

- non-academic - not academic;

- non-literate - illiterate;

- non-professional - an undergraduate specialist;

- reader-non - person who has not mastered reading skills after Navier - tun - ing conventional methods (Nikoshkova, 2001: 206);

- non-attendance - non-attendance:

- curriculum-non - an aspect of school life in which learning takes place outside the program and outside the educational institution (for example, in a school club).

The prefix sub - functions in non-transposing models and the terms formed with its help can have the following meanings:

- subconsious - subconscious;

- subdean - deputy dean;

Antonymic to this prefix is the prefix super- "higher official position":

- superintendant - commandant.

The given examples of word formation of pedagogical terms with the help of prefixes confirm the opinion of GA Ufimtseva that "in the case of prefixation, the essence of the name is contained in the motivating word, and the prefix only specifies the basis, but does not indicate the class of objects - the class of objects is marked by the defining word (basis)" (Ufimtseva, 1977: 56). 


\section{Suffix as a word-making method}

The suffix is a post-root affixal morpheme separated from the word form. The suffix is characterized by its ability to classify certain semantic groups of words. Attaching the suffix to a productive basis includes this last class, which is marked with a given suffix, that is, the suffixes used to create terms, refer words to a certain lexical-morphological category, indicate the part of the language to which the terminological word belongs - they do not have their semantic meanings.

Suffixes can be classified according to several criteria. First, we select purely English suffixes -ness, -er; borrowed suffixes -able, -tion, -ism; secondly, productive in pedagogical terminology -action (-tion), -er, -ing, -ment; by common abstract categorical value: -er/-or agent suffixes, -ant, -dom prefix.

In modern English pedagogical terminology, the suffix -er (one who performs a certain action is bound, involved in a certain action) is characterized by a high level of productivity. With the help of agent suffixes, names of persons are formed by profession and type of activity, in particular, the names of persons associated with the process of training and education:

- beginner - beginner;

- crammer - tutor;

- learner - $\boldsymbol{a}$ student;

- lecturer - lecturer;

- teacher - teacher;

- chancellor - rector;

- educator - educator;

- instructor - teacher, lecturer;

The suffix - er with the value of qualification joins the adjective bases and provides specific characteristics, human characteristics: fresher - freshman.

With the help of suffixes - ism, - ness, - ship, - dom abstract nouns are formed. Productive suffix - ation / - tion at - connects - chys to verbal stems, forming nouns that are important "processes and activities":

- accreditation - accreditation;

- certification - certificate, certificate;

- collaboration - cooperation;

- education - education;

- explanation - explanation;

- evaluation - evaluation;

- promotion - support, encouragement;

The names of theories and concepts are formed with the suffix -ism:

- behaviorism - behaviorism;

- essentialism - a learning strategy that focuses on skills such as reading, writing, math at the initial stage.

- existentialism - $a$ philosophy that studies the ways in which an individual creates his own view and purpose of life.

With this suffix are formed terms that have the meaning of a certain state: passivism -assistantship - postgraduate scholarship;

- associateship - the salary of an intern;

- fellowship - scholarship;

- graduateship - postgraduate scholarship; 
- instructorship - educator's salary;

- internship - internship;

- scholarship - scholarship.

The purely English suffix -dom forms abstract nouns with the meaning of position, status or rank:

- professordom - professor;

- teacherdom - teaching;

- wisdom - wisdom.

Terms with the suffix -ing are mainly formed from verb bases and denote processes and actions:

- bus (s) ing - transportation of schoolchildren by bus;

- monitoring - monitoring of the educational process;

- passing - successful passing of tests, exams;

- rating - rating;

- reading - reading;

- schooling - training;

- streaming - the distribution of students in different streams.

- studying - learning;

- teaching - teaching; success.

- tracking - the distribution of students according to their abilities, learning

Thus, the most productive in the English terminology of education are the suffixes -ation / -tion, -er / -or, -ing . Timing formed on to - to - mo - hoyu considered suffix denoting person-figure process, action, acting - ness, the result of actions position.

As rightly noted by MM Polyuzhin, "native speakers learn not only the series of words, but also the rules of their birth, ... (there is) a mental representation of the derived words, which are stored not so much as individual elements as models of combinatorics of their constituent units" (Poluzhin, 1999:47).

\section{Conversion in English-language methodological terminology}

Conversion is the process of creating new words in different parts of speech without adding any derivational elements, so that the basic form of the original words and the form of derived words are homonymous. Conversion in word formation is also interpreted as a morphological transposition, in which the transition of a word from one part of speech to another occurs without changing the basis of the word. O.I. Smyrnytsky considered the only word-forming tool in the conversion of only the paradigm, ie the morphological design of the word. The famous Ukrainian Englishman Yu.O. Zhluktenko made an in-depth analysis of the theory of conversion O.I. Smyrnytsky and came to the conclusion that modern English conversion is a morphological and syntactic way of word formation, in which word-forming means are both grammatical compatibility and word form - paradigm. The act of forming a new word by conversion is the use of the basis of the creative word to design it into another word in terms of another grammatical compatibility, typical of the second part of speech (Zhluktenko, 1958: 64).

This linguistic phenomenon is illustrated by the following pedagogical terms:

- graduate - a graduate and to graduate - to graduate;

- lecture - lecture and to lecture - to give a lecture;

- schedule - schedule and to schedule - to make a schedule; 
- tutor - tutor and to tutor - to give private lessons.

The main reason for the widespread conversion in modern English, as noted by the famous Englishmen I. Arnold and O. Meshkov, is the lack of morphological indicators of parts of speech in the language. Even O. Jespersen vidmichav that every Englishman "recognizes the advantage that it is language, and self - shall make already existing words to serve in the new functions".

The question of the direction of derivation of conversion pairs remains important, especially for $\mathbf{N} ®$ discipline - discipline, discipline; discipline as a branch of knowledge;

- to discipline - to establish strict discipline;

- interview - conversation;

- to interview - to talk;

- overstudy - overload with classes;

- to overstudy - to be overloaded with lessons, to study too much.

In modern methodical terminology, a large number of deadjective nouns function, which were formed not by conversion, but rather by an ellipse - instead of a phrase consisting of an adjective and a noun used:

- academicals - university form;

- elective - a discipline in a school, college, which is chosen at will;

- extracurriculars - extracurricular, extracurricular activities;

- oral - oral exam.

By their structure, most conversion terms are simple and non-derivative. Example:

- test - control work, exam;

- to test - to test, to check by means of tests;

- control - control, check and to control - to control.

But some converted terms are formed from bases, which in turn are formed by affixation: understanding - understanding, mind smart $\mathbf{N}[\mathbf{V}+$ ing $] \mathbf{A}$; recall - memory mention $\mathbf{N}[$ re $+\mathbf{V}] \mathbf{A}$; recall - memory mention $\mathbf{N}[\mathbf{r e}+\mathbf{V}] \rightarrow \mathbf{V}$. In some cases, the base can be complex nouns of structural type $[\mathbf{N}+\mathbf{N}] \rightarrow \mathbf{V}$, for example: timetable $\rightarrow$ to timetable - schedule; schedule.

Thus, with the help of conversion, any noun can motivate a new verb, serve as a source of verb nouns, and an adjective that denotes a sign or property of a phenomenon, can form the basis of a new process or object.

\section{Conclusions}

Structural and semantic analysis of English methodological terms allowed us to draw the following conclusions. According to the word-forming structure, English-language methodological terms are divided into three types: time - simple word, term - a compound word, term. The terms of the first two types are created by means of morphological and lexical-semantic methods; the syntactic method is used to create terms of the third type. The most productive kind of morphological terminology - creation is affixed manner in which the most productive suffix.

In affixal formations, prefixes have the greatest performance: re-, non-, un-, under- and extensions: -ation / -tion, -er / -or, -ing. 


\section{References}

Carev P.V. (1984) Produktivnoe imennoe slovoobrazovanie v sovremennom anglijskom yazyke [Productive noun word formation in modern English]. Moscow: Izd-vo Mosk. Un-ta, [in Russian].

Danilenko V.P. (1973) O terminologicheskom slovoobrazovanii [About terminological word formation]. Minsk. [in Russian].

Farris P. J. (1996) Teaching, bearing the Torch. Northern Illinois University, Brown and Benchmark Publishers. [in English].

Jay M. Shafritz, Richard P. Koeppe, Elizabeth W. Soper (1988). The Facts on File dictionary of education. New York; Oxford; Facts on File. [in English]

Kiyak T.R. (1989) Lingvisticheskie aspekty terminovedeniya. K: UMK VO. [in Russian].

Kubryakova E.S. (1972) Slovoobrazovanie [Word formation]. Moscow: Nauka. [in Russian].

Lesheva L.M. (1990) K voprosu o chasterechnyh osobennostyah vnutrislovnyh soderzhatelnyh svyazej. [On the question of part-of-speech features of intraword content connections] Minsk [in Russian].

Nikoshkova E.V. (2001) Anglo-russkij slovar po psihologii [English-Russian Dictionary of Psychology]. Moscow: RUSSO. [in Russian].

Poliuzhyn M.M. (1999) Funktsionalnyi $i$ kohnityvnyi aspekty anhliiskoho slovotvorennia. [Functional and cognitive aspects of the English word creation]. Uzhhorod: Zakarpattia. [in Ukrainian].

Stepanov Yu.S. (1977) Nominaciya, semantika, semiologiya Yazykovaya nominaciya (obshie voprosy). [Nomination, semantics, semiology]. Moscow:Nauka, 1977. [in Russian].

Ufimceva A.A. (1977) Lingvisticheskaya sushnost i aspekty nominacii. Yazykovaya nominaciya: Obshie voprosy. [Linguistic essence and aspects of nomination] Moscow: Nauka. [in Russian]. Vorojskij F.S. (1998) Sistematizirovannyj tolkovyj slovar po informatike: Vvodnyj kurs po informatike $i$ vychislitelnoj tehnike v terminah [Systematized Explanatory Dictionary of Informatics: An Introductory Course in Informatics and Computing in Terms] Moscow:Libereya. [in Russian].

Zhluktenko Yu.A. (1958) Konversiya v sovremennom anglijskom yazyke kak morfologo-sintaksicheskij sposob slovoobrazovaniya. [Productive noun word formation in modern English]. Moscow: Nauka. [in Russian].

Zhuravleva T.A. (1998) Osobennosti terminologicheskoj nominacii. [Features of terminological nomination] Monografiya. Doneck, AOOT "Donbass"”. [in Ukrainian]. 